\title{
Analisa Rasio Likuiditas Dalam Mengukur Kinerja Keuangan PT. Mustika Ratu, Tbk (Tahun 2010-2016)
}

\author{
Selvia Nuriasari* \\ Jurusan Ekonomi Islam, IAIN Metro, Indonesia
}

\begin{abstract}
:
Financial ratio analysis is very important for company, one of which is management that need to analysis of financial performance and the results are used to design business plan, evaluate management and company performance. Liquidity ratio is one of the financial ratios used with the aim of measuring the ability of a company to pay a current liability. and to measure the company's ability to finance the company's operating activities. PT. Mustika Ratu, Tbk is was one of the national companies in the manufacturing sector of herbal medicine, cosmetics and ingredients for beauty care which experienced a decline in sales, which among others was due to the large number of competitors and the entry of products from abroad. A decrease in sales will have an impact on the ability of PT. Mustika Ratu, Tbk in fulfilling its liabilites includes current liabilities, especially when it is seen that most of its raw materials are still imported from abroad so there is the possibility of adding "outside funds" to buy these raw materials to meet the needs so that the sales target is achieved. The addition of these obligations, including current liabilities will have an impact on the increase in the burden of PT. Mustika Ratu, Tbk in paying current liabilities. So here the researcher is interested in raising the problem, namely seeing the ability of PT. Mustika Ratu, Tbk in fulfilling its liabilities in paying current liabilities by using liquidity ratios. The formulas that will be used in analyzing the ability to current liabilities in PT. Mustika Ratu, Tbk are current ratio, quick ratio, cash ratio, net working to capital ratio, and inventory to net working capital ratio.
\end{abstract}

Keywords: financial ratio, current liabilites, financial performance

\section{PENDAHULUAN}

Laporan keuangan sebagai media komunikasi perusahaan dan para pemegang kepentingan bisnis ini memberikan berbagai informasi kegiatan bisnis perusahaan dalam bentuk data-data kuantitatif. Informasi tersebut bersifat historis karena merupakan rangkuman dari kegiatan bisnis perusahaan di masa lalu yang berbentuk angka - angka yang terdiri dari neraca, laporan laba-rugi, laporan arus kas dan laporan perubahan modal. Laporan keuangan ini menjadi sumber data utama dalam menilai kinerja

*Email korespondensi:

selviasari7@gmail.com keuangan perusahaan yang dapat dinilai dengan cara menganalisis laporan keuangan perusahaan tersebut dengan tujuan untuk mengetahui kondisi keuangan perusahaan, apakah dalam kondisi baik atau tidak yang dari hasil analisa tersebut akan digunakan untuk merencanakan bisnis dari sisi perusahaan dan untuk melihat serta mengevaluasi kinerja keuangan perusahaan dan manajemen secara keseluruhan.

Salah satu cara dalam menilai kinerja keuangan perusahaan dan palings ering digunakan adalah rasio keuangan. Rasio keuangan adalah salah satu alat dalam menganalisa kinerja keuangan perusahaan dengan cara membandingkan data - data yang ada dalam laporan keuangan untuk satu 
periode dan hasilnya dalam bentuk rasio atau prosentase, dimana dalam mengukur baik atau tidaknya kondisi keuangan perusahaan tersebut dapat menggunakan rasio rata-rata industry yang berlaku secara umum.

Analisis rasio keuangan sangat bermanfaat bagi para pihak yang berkaitan dengan perusahaan salah satunya adalah manajemen perusahaan yang membutuhkan alat untuk mengukur kinerja keuangan perusahaan dan hasilnya digunakan untuk merancang perencanaan bisnis perusahaan dimasa depannya dan juga untuk mengevaluasi kinerja manajemen dan perusahaan dengan cara membandingkannya dengan rata - rata industry, sedangkan bagi para kreditur dapat digunakan untuk memperkirakan potensi resiko yang akan dihadapi dikaitkan dengan adanya jaminan kelangsungan pembayaran bunga dan pengembalian pokok pinjamannya. Analisa rasio juga bermanfaat bagi para investor dalam mengevaluasi nilai saham dan jaminan atas keamanan dana yang akan ditanamkan pada suatu perusahaan. Dengan demikian analisa rasio keuangan yang dapat diterapkan atau digunakan pada setiap model analisis, baik model yang digunakan oleh manajemen untuk pengambilan keputusan jangka pendek maupun jangka panjang, peningkatan efisiensi dan efektivitas operasi serta untuk mengevaluasi dan meningkatkan kinerja (corporate financial management model), ${ }^{1}$ dan lain sebagainya.

Rasio likuditas adalah salah satu rasio keuangan yang digunakan dengan tujuan untuk mengukur kemampuan sebuah perusahaan dalam membayar utang atau kewajiban yang pendeknya secara tepat waktu $^{2}$ dan untuk mengukur kemampuan perusahaan dalam membiayai aktivitas operasi perusahaan. Inilah tujuan dari penelitian ini adalah untuk mengetahui kinerja keuangan pada PT. Mustika Ratu Tbk

1 S. Munawir. Analisis Informasi Keuangan. (Yogyakarta : Liberty, 2008) Hal. 83

2 Irham fahmi. Analisis Laporan Keuangan (Bandung : Alfabeta, 2014)Hal. 121 ditinjau dari analisis rasio likuditas dari tahun 2010 sampai tahun 2016.

PT. Mustika Ratu, Tbk adalah salah satu perusahaan nasional yang bergerak di sektor industri pembuatan jamu, kosmetik dan bahan-bahan untuk perawatan kecantikan. Saat ini kondisi keuangan perusahaan ini mengalami penurunan yang disebabkan antara lain semakin banyaknya perusahaan pesaing dan masuknya produk produk dari luar negeri dengan harga yang lebih murah seperti dari Negara Cina. Hal ini diperkuat dari berita pada tahun 2014, yaitu sebagai berikut :

"Selain masalah distribusi, masuknya produk-produk kecantikan dari Cina juga membuat konsumen mulai berpaling untuk mencoba produk asal Negeri Panda. Kenaikan harga bahan bakar minyak, upah minimum provinsi, dan melemahnya rupiah, juga turut menghambat Mustika Ratu. "Melemahnya nilai rupiah hingga Rp 12.128 per dolar Amerika Serikat pada 2013, berdampak signifikan bagi perseroan, terutama untuk pengadaan bahan baku impor" $^{3}$

Penurunan penjualan ini tentunya akan berdampak terhadap kemampuan PT. Mustika Ratu, TBK dalam memenuhi kewajiban termasuk kewajiban jangka pendek, apalagi jika dilihat bahwa bahan baku nya kebanyakan masih impor dari luar negeri yang artinya akan menambah "beban" PT. Mustika Ratu, TBK yaitu adanya kemungkinan penambahan "dana dari luar' untuk membeli bahan baku tersebut demi memenuhi kebutuhan konsumen sehingga target penjualan dapat tercapai. Penambahan dana dari luar tersebut atau kewajiban, baik kewajiban jangka pendek dan kewajiban jangka panjang, akan berdampak pada turunnya kemampuan PT. Mustika Ratu, TBK dalam membayar kewajiban ke pihak tersebut, terutama kewajiban jangka pendek.

\footnotetext{
${ }^{3}$ Tempo.co. tanggal : 11 Juni 2014. Alamat : https://bisnis.tempo.co/read/584236/penjualanmustika-ratu-terkendala-distribusi
} 
Maka disini peneliti tertarik untuk mengangkat masalah tersebut, yaitu melihat kemampuan PT. Mustika Ratu, TBK dalam memenuhi kewajibannya dalam membayar utang jangka pendek dengan menggunakan rasio likuiditas. Adapun rumus - rumus yang akan digunakan dalam menganalisa kemampuan membayar utang jangka pendek PT. Mustika Ratu, TBK adalah rasio lancar, rasio cepat, rasio kas, rasio modal kerja bersih, dan rasio persediaan terhadap modal kerja bersih.

\section{KAJIAN LITERATUR \\ Definisi Rasio Likuiditas}

Rasio likuiditas adalah rasio yang mengukur kemampuan perusahaan dalam memenuhi kewajiban jangka pendeknya. Rasio ini penting karenan kegagalan dalam membayar kewajiban jangka pendek dapat menyebabkan kebangkrutan perusahaan. Rasio ini mengukur pada kemampuan likuiditas jangka pendek perusahaan dengan lihat aktiva lancar perusahaan terhadap hutang lancarnya (hutang yang dimaksud disini adalah kewajiban perusahaan). ${ }^{4}$

\section{Tujuan Rasio Likuiditas}

Sebagaimana dijelaskan diatas, maka dapat diketahui bahwa tujuan dari analisa rasio likuiditas adalah melihat kemampuan perusahaan dalam membayar kewajiban jangka pendek secara tepat waktu

\section{Rumus-rumus Rasio Likuiditas}

Rumus-rumus rasio likuiditas ada banyak, namun disini peneliti hanya akan menggunakan empat rumus saja. Adapun rumus-rumus tersebut adalah sebagai berikut:

\section{a. Rasio Lancar atau Current Ratio}

Rasio lancar adalah rasio yang melihat

\footnotetext{
${ }^{4}$ Irham fahmi. Analisis Laporan ..., Hal. 116

5 Lyn M. Fraser dan Allen Ormiston, Memahami Laporan Keuangan Edisi KeTujuh (Jakarta : Indeks, 2008),hal. 223, dikutip oleh Irham Fahmi, Analisa Laporan..., hal 121.

${ }^{6}$ Irham Fahmi, Analisa Laporan..., hal 121.

${ }^{7}$ Irham Fahmi, Analisa Laporan..., hal 124.
}

kemampuan perusahaan dalam membayar seluruh kewajiban lancarnya dengan menggunakan seluruh asset lancarnya. Menurut Irham Fahmi, rasio lancar adalah ukuran yang umum digunakan atas solvensi jangka pendek, kemampuan suatu perusahaan memenuhi kebutuhan utang ketika jatuh tempo. ${ }^{5}$ Rasio lancar ini memiliki kelemahannya yaitu hanya menjelaskan secara kasar tentang kemampuan perusahaan dalam membayar kewajiban jangka pendeknya sehingga, menurut Irham Fahmi, perlu adanya dukungan analisa secara kualitatif secara lebih komprehensif. ${ }^{6}$

Berkaitan dengan standar kesehatan rasio likuiditas, Irham Fahmi mengatakan bahwa kondisi perusahaan yang memiliki current ratio yang baik adalah dianggap sebagia perusahaan yang baik dan bagus, namun jika current ratio (rasio lancar) terlalu tinggi juga dianggap tidak baik. ${ }^{7}$ Irham Fahmi mengutip pendapat dari Samuel C. Weaver dan J. Fred Weston, bahwa setiap nilai ekstrim dapat mengindikasikan adanya masalah. ${ }^{8}$

Berkaitan hal tersebut diatas, Irham Fahmi memberikan contoh yaitu rasio lancar sebesar 8,00 dapat mengindikasikan adanya penimbunan kas, banyaknya piutang yang tidak tertagih, penumpukan persediaan, tidak efisiennya pemanfaatan "pembiayaan" gratis dari pemerintah dan rendahnya pinjaman jangka pendek. ${ }^{9}$

Bagi pihak manajer, rasio lancar yang tinggi dianggap baik bergutu juga dengan kreditur karna dianggap semakin aman dalam membayar atau melunasi kewajiban jangka pendeknya, akan tetapi bagi para pemegang saham dianggap kurang baik karena, sebagiaman dilihat dari uraian diatas, bahwa tingginya rasio lancar, ada indikasi perusahaan terutama manajer perusahaan

8 Samuel C. Weaver dan J. Fred Weston. Finance and Accounting for nonfinancial Managers. Memahami Laporan keuangan dan Akuntansi Sekelas MBA (Jakarta : PT. Buana Ilmu Populer, 2001), hal. 220

\footnotetext{
${ }^{9}$ Irham Fahmi, Analisa Laporan..., hal 124.
} 
kurang mampu mengelola asset lancar secara baik dan efektif dalam menghasilkan laba perusahaan. Adapun rumus rasio lancar adalah sebagai berikut

$$
\text { Rasio Lancar }=\frac{\text { aktiva lancar }}{\text { kewajiban lancar }}
$$

Keterangan :

1) Aktiva lancar atau disebut juga dengan asset lancar yaitu total aktiva lancar dalam satu periode.

2) Kewajiban lancar atau disebut juga dengan utang lancar total kewajiban lancar dalam satu periode.

3) Standar kesehatan industry atau rata - rata industry yang digunakan dalam penelitian ini adalah $2: 1$. Atau 200\%. Jika dibawah 200\% maka dapat dikatakan ill-likuid. Artinya aktiva lancar dikatakan sehat atau likuid jika 2 kali lipat dari kewajiban lancar.

\section{b. Rasio Cepat atau Quick Ratio}

Rasio cepat adalah rasio yang mengukur kemampuan perusahaan dalam membayar kewajiban jangka pendeknya dengan aktiva jangka pendek dikurangi persediaan. Hal ini dikarenakan persediaan membutuhkan waktu yang lebih lama untuk diuangkan atau berubah menjadi cash asset. Rasio cepat ini standarnya adalah 1:1 atau $100 \%$ dapat dikatakan likuid. ${ }^{10}$ maka jika dibawah $100 \%$, maka dapat dikatakan ill-likuid. Adapun rumusnya adalah sebagia berikut :

\section{c. Rasio Kas atau Cash Ratio}

Rasio kas adalah rasio yang mengukur kemampuan perusahaan membayar kewajiban jangka pendeknya dengan menggunakan kas. Rasio ini dikatakan sehat jika tidak dibawah 50\%. ${ }^{11}$ akan tetapi jika terlalu tinggi, sebagaimana telah dijelaskan diatas yaitu ada indikasi, salah satunya penimbunan kas artinya kas tidak digunakna secar abaik dan efektif dalam menghasilkan

\footnotetext{
10 Bambang Riyanto. Dasar - dasar Pembelanjaan Perusahaan. (Yogyakarta : BPFE, 2001), hal. 27

11 Kasmir. Analisa Laporan Keuangan. (Jakarta : PT. Raja Grafindo Persada, 2008), hal. 140
}

laba. Maka, untuk dapat memperkuat atau memperjelas kewajaran dari tinggi atau rendahnya rasio cepat dapat digunakan salah satunya rasio perputaran kas. Adapun rumus rasio kas adalah :

$$
\text { Rasio Kas }=\frac{\text { kas }}{\text { kewajiban lancar }}
$$

\section{d. Rasio modal kerja bersih ${ }^{12}$}

Modal kerja merupakan suatu ukuran dari likuiditas perusahaan. Sumber modal kerja adalah pendapatan bersih, peningkatan kewajiban yang tidak lancar, kenaikan ekuitas pemegang saham dan penurunan aktiva yang tidak lancar. Adapun rumusnya adalah :

\section{Rasio modal kerja bersih = aktiva lancar - utang lancar}

\section{e. Rasio Persediaan Terhadap Modal Kerja Bersih}

Rasio ini digunakan untuk mengukur atau membandingkan antara jumlah persediaan yang ada dalam modal kerja perusahaan. Modal kerja tersebut terdiri dari pengurangan antar aktiva lancar dan utang lancar.${ }^{13}$ Adapun rumusnya adalah sebagai berikut :

Rasio modal kerja bersih $=\frac{\text { persediaan }}{\text { modal kerja bersih }}$

Rasio ini dikatakan sehat jika rasionya minimal $12 \%,{ }^{14}$ maka jika dibawah $12 \%$, kondisi rasio modal kerja bersihnya dikatakan ill-likuid dan jika minimal dan diatas $12 \%$ maka dapat dikatakan likuid.

\section{Kinerja Keuangan Perusahaan ${ }^{15}$}

Untuk memutuskan suatu badan usaha atau suatu perusahaan memiliki kualitas yang baik maka ada dua penilaian yang paling dominan yang dapat dijadikan acuan untuk melihat badan usaha / perusahaan tersebut

\footnotetext{
${ }^{12}$ Irham Fahmi, Analisa Laporan ..., hal 126

${ }^{13}$ Kasmir. Analisa Laporan ..., hal. 141

${ }^{14}$ Kasmir. Analisa Laporan ..., hal. 142

15 Irham Fahmi, Analisa Laporan..., hal 238-
} 
menjalankan suatu kaidah - kaidah manajemen yang baik. Penilaian ini dapat dilakukan dengan melihat sisi kinerja keuangan dan kinerja non keuangan.

Kinerja keuangan melihat pada laporan keuangan yang dimiliki badan usaha / perushaan yang bersangkutan dan itu tercermin dari informasi yang diperoleh dari neraca, laporan laba rugi dan laporan arus kas serta hal - hal lain yang turut mendukung sebagai penguat penilaian kinerja keuangan tersebut. Rasio keuangan adalah salah satu alat yang digunakan dalam mengukur kinerja keuangan perusahaan tersebut.

\section{METODE}

Sumber data dalam penelitian ini adalah sumber data sekunder yaitu laporan keuangan PT. Mustika Ratu,Tbk dari tahun 2010 sampai dengan tahun 2016. Jenis datanya adalah jenis data kuantitatif yaitu laporan keuangan Pt. Mustika Ratu, Tbk. Teknik pengumpulan datanya adalah dokumentasi serta dalam menganalisis data, peneliti menggunakan rumus - rumus rasio likuiditas yaitu rasio lancar, rasio cepat, rasio kas, rasio modal kerja bersih dan rasio persediaan terhadap modal kerja bersih.

\section{HASIL DAN PEMBAHASAN}

Sejarah Singkat PT. Mustika Ratu, Tbk ${ }^{16}$

Mustika Ratu Tbk (MRAT) didirikan 14

Maret 1978 dan mulai beroperasi secara komersial pada tahun 1978. Kantor pusat MRAT berlokasi di Graha Mustika Ratu, Penthouse Floor, Jalan Gatot Subroto Kav. 74-75, Jakarta Selatan kode pos 12870 Indonesia dan pabrik berlokasi di Jalan Raya Bogor KM. 26,4 Ciracas, Jakarta Timur kode pos 13740. Pemegang saham yang memiliki 5\% atau lebih saham Mustika Ratu Tbk, yaitu: PT Mustika Ratu Investama

http://britama.com/index.php/2012/12/sejarah-danprofil-singkat-mrat/ (pengendali) (71,26\%) dan Mellon S/A Investors Pacific International, Jakarta $(8,91 \%)$. Berdasarkan Anggaran Dasar Perusahaan, ruang lingkup kegiatan MRAT meliputi pabrikasi, perdagangan dan distribusi jamu dan kosmetik tradisional serta minuman sehat, perawatan kecantikan, serta kegiatan usaha lain yang berkaitan. Merekmerek yang dimiliki MRAT, antara lain: Mustika Ratu, Mustika Puteri, Bask, Biocell, Moor's, Ratu Mas, Taman Sari Royal Heritage Spa. Pada tanggal 28 Juni 1995, MRAT memperoleh pernyataan efektif dari Bapepam-LK untuk melakukan Penawaran Umum Perdana Saham MRAT (IPO) kepada masyarakat sebanyak 27.000.000 dengan nilai nominal Rp500,- per saham dengan harga penawaran Rp2.600,- per saham. Saham-saham tersebut dicatatkan pada Bursa Efek Indonesia (BEI) pada tanggal 27 Juli 1995.

\section{Analisa Rasio Likuiditas PT. Mustika Ratu, Tbk Tahun 2010 - 2016 \\ a. Rasio Lancar}

Tabel 1 : Perhitungan Rasio Lancar PT. Mustika Ratu, Tbk. Tahun 2010-2016 ${ }^{17}$

\begin{tabular}{|ccc|}
\hline \multicolumn{1}{|c|}{$(\mathrm{RAH})$} & ASET LANCAR & UTANG LANCAR (Rp) \\
\hline 2010 & $1,524,322,000$ & $1,451,611,000$ \\
2011 & $1,567,335,000$ & $1,708,305,000$ \\
2012 & $352,880,309,210$ & $58,646,329,121$ \\
2013 & $313,664,019,262$ & $51,810,424,520$ \\
2014 & $376,694,285,634$ & $104,267,201,912$ \\
2015 & $380,988,168,593$ & $102,898,339,772$ \\
2016 & $372,731,501,477$ & $93,871,952,310$ \\
\hline RASIO & CR & \\
\hline 2010 & 1.05 & RI \\
2011 & 0.92 & $2 X$ \\
2012 & 6.02 & \\
2013 & 6.05 & \\
2014 & 3.61 & \\
2015 & 3.70 & \\
2016 & 3.97 & \\
\hline
\end{tabular}

\footnotetext{
${ }^{17}$ Data diolah dari laporan keuangan. Sumber : www.idx.co.id
} 
Berdasarkan perhitungan diatas, maka dapat diketahui bahwa rasio lancar PT. Mustika Ratu, Tbk. Dari tahun 2010 sampai dengan tahun 2016 berada diatas rata - rata industry yaitu diatas dua kali, atau dalam kondisi likuid. Akan tetapi rasio lancarnya mengalami penurunan dari tahun ke tahun, yaitu dari 7,61 kali pada tahun 2010 turun hingga 3,97 kali pada tahun 2016, dimana penurunan terendah terjadi pada tahun 2014, yaitu sebesar 3,61 kali. Hal ini disebabkan karena naiknya utang lancar yaitu dari Rp. 51,810,424,520 ke Rp. 104,267,201,912.

Naiknya utang lancar tahun 2014 antara lain disebabkan oleh naiknya utang bank jangka pendek yang merupakan pinjaman MRAT ke Bank Mandiri dalam bentuk kredit modal kerja, utang usaha pihak ketiga mengalami kenaikan yang timbul atas pembelian bahan baku, suku cadang, perlengkapan pabrik dan/atau jasa dari pihak ketiga, kemudian pinjaman bank jangka panjang yang jatuh tempo mengalami kenaikan yang digunakan untuk pembelian mesin. ${ }^{18}$

Dapat disimpulkan bahwa rasio lancar dapat dikatakan likuid yang mana kenaikan Rasio lancar ini dikarenakan naiknya utang lancar yang digunakan untuk menambah modal kerja dan pembelian mesin.

\section{b. Rasio Cepat}

Tabel 2 : Perhitungan Rasio Cepat PT. Mustika Ratu, Tbk. Tahun 2010-2016 ${ }^{19}$

\begin{tabular}{|c|c|c|c|}
\hline TAHUN & $\begin{array}{l}\text { PERSEDIAAN } \\
\text { (Rp) }\end{array}$ & $\begin{array}{l}\text { ASET LANCAR } \\
\text { (Rp) }\end{array}$ & $\begin{array}{l}\text { UTANG LANCAR } \\
(\mathrm{Rp})\end{array}$ \\
\hline 2010 & $400,784,000$ & $1,524,322,000$ & $1,451,611,000$ \\
\hline 2011 & $462,013,000$ & $1,567,335,000$ & $1,708,305,000$ \\
\hline 2012 & $63,429,469,813$ & $352,880,309,210$ & $58,646,329,121$ \\
\hline 2013 & $68,057,379,761$ & $313,664,019,262$ & $51,810,424,520$ \\
\hline 2014 & $86,415,542,961$ & $376,694,285,634$ & $104,267,201,912$ \\
\hline 2015 & $78,917,127,036$ & $380,988,168,593$ & $102,898,339,772$ \\
\hline 2016 & $90,719,293,111$ & $372,731,501,477$ & $93,871,952,310$ \\
\hline RASIO & QT & & RI \\
\hline 2010 & 0.77 & & \\
\hline 2011 & 0.65 & & \\
\hline 2012 & 4.94 & & \\
\hline 2013 & 4.74 & & $1,5 \mathrm{x}$ \\
\hline 2014 & 2.78 & & \\
\hline 2015 & 2.94 & & \\
\hline 2016 & 3.00 & & \\
\hline
\end{tabular}

${ }^{18}$ Data bersumber dari laporan tahunan MRAT tahun 2013 - 2015 halaman 54 - 66
Berdasarkan perhitungan diatas, maka dapat diketahui bahwa rasio cepat PT. Mustika Ratu, Tbk. Dari tahun 2010 sampai tahun 2011 berada dibawah rata - rata industry yaitu dibawah 1,5 kali, atau dalam kondisi Ill-likuid. Rasio ini mengalami kenaikan tertingi pada tahun 2012 yaitu 4,94 kali. Sedangkan tahun berikutnya cenderung turun, dan meskipun naik pada tahun 2016 yaitu sebesar 3,00 kali tetapi belum mampu mencapai 4,94 kali tahun 2012.

Berdasarkan table tersebut diatas, maka dapat disimpulkan bahwa kemampuan PT. Mustika Ratu, Tbk membayar kewajiban lancar setekah dikurangi persediaan tahun 2010 ke 2011 ill-likuid dikarenakan naiknya utang lancar yaitu dari Rp. 51,810,424,520 ke Rp. 104,267,201,912. Kemudian tahun 2012 ke 2016 meskipun turun tetapi dalam kondisi likuid, dimana tahun 2014 merupakan penurunan terendah yaitusebesar $2,78 \mathrm{kali}$ dikarenakan naiknya utang lancar yang mencapai Rp. 52456777392,--.

Jika dilihat tahun 2016, rasio cepat perusahaan ini mengalami kenaikan dibandingkan tahun 2015, yaitu dari 2,94 kali ke 3 kali. Kenaikan rasio cepat ini disebabkan oleh turunnya utang lancar dari Rp. 103 Milyar ke Rp. 94 Milyar yaitu dikarenakan turunnya utang usaha, utang lain - lain, pinjaman pihak berelasi, utang bank jangka panjang yang jatuh tempo. Meskipun mengalami kenaikan pada rasio cepat, yang disebabkan turunnya utang lancar, tetapi yang menjadi catatan disini adalah terjadinya penurunan aset lancar. Turunnya aset lancar disebabkan turunnya kas dan setara kas, piutang usaha mengalami penurunan, dan penurunan biaya dibayar dimuka.

\footnotetext{
${ }^{19}$ Data diolah dari laporan keuangan. Sumber : www.idx.co.id
} 
c. Rasio Kas

Tabel 3 : Perhitungan Rasio Kas

PT. Mustika Ratu, Tbk.

Tahun 2010-2016 ${ }^{20}$

\begin{tabular}{|ccc|}
\hline TAHUN & KAS (Rp) & $\begin{array}{c}\text { UTANG } \\
\text { LANCAR(Rp) }\end{array}$ \\
\hline 2010 & $999,240,000$ & $1,451,611,000$ \\
2011 & $918,974,000$ & $1,708,305,000$ \\
2012 & $59,560,929,387$ & $58,646,329,121$ \\
2013 & $55,331,076,348$ & $51,810,424,520$ \\
2014 & $36,038,513,893$ & $104,267,201,912$ \\
2015 & $36,273,186,840$ & $102,898,339,772$ \\
2016 & $24,376,706,961$ & $93,871,952,310$ \\
\hline Rasio & CAR & RI \\
\hline 2010 & $68.84 \%$ & \\
2011 & $53.79 \%$ & \\
2012 & $101.56 \%$ & \\
2013 & $106.80 \%$ & $50 \%$ \\
2014 & $34.56 \%$ & \\
2015 & $35.25 \%$ & \\
2016 & $25.97 \%$ & \\
\hline
\end{tabular}

Berdasarkan perhitungan diatas, dapat diketahui bahwa rasio kas PT. Mustika Ratu, Tbk. Dari tahun 2010 sampai tahun 2013 berada diatas rata - rata industry yaitu diatas $50 \%$, atau dalam kondisi likuid tetapi kenaikannya cukup tinggi terutama tahun 2012 dan 2013 yang ada indikasi terjadinya kas yang menganggur.. Sedangkan tahun 2014 sampai tahun 2016 mengalami penurunan dan ill-likuid, kecuali tahun 2015 yang naik sebesar 35,35 $\%$ meskipun tetap dibawah rata-rata industry atau ill-likuid.

Berdasarkan table tersebut diatas, maka dapat disimpulkan bahwa kemampuan PT. Mustika Ratu, Tbk membayar kewajiban lancar dengan menggunakan kas yang ada dari tahun 2010 sampai tahun 2013 dalam kondisi likuid artinya masih mampu membayar kewajiban lancarnya secara tepat waktu, tetapi tahun

${ }^{20}$ Data diolah dari laporan keuangan. Sumber : www.idx.co.id
2014 sampai tahun 2016 mengalami penurunan dan ill-likuid, dikarenakan naiknya utang lancar tanpa dibarengi dengan naiknya kas. Dimana kas dari tahun 2014 sampai 2016 turun, yaitu secara berurutan: Rp. 36,038,513,893,-; Rp. 36,273,186,840,-; dan Rp. 24,376,706,961,-- Penurunan kas tahun 2016 merupakan penurunan terendah selama 5 tahun terakhir salah satunya diakibatkan turunnya penjualan.

\section{d. Rasio Modal Kerja Bersih \\ Tabel 4 : Perhitungan Rasio Modal Kerja Bersih PT. Mustika Ratu, Tbk. Tahun 2010-2016 ${ }^{21}$}

\begin{tabular}{|ccc|}
\hline TAHUN & $\begin{array}{c}\text { ASET LANCAR } \\
(\mathrm{Rp})\end{array}$ & $\begin{array}{c}\text { UTANG } \\
\text { LANCAR(Rp) }\end{array}$ \\
2010 & $1,524,322,000$ & $1,451,611,000$ \\
2011 & $1,567,335,000$ & $1,708,305,000$ \\
2012 & $352,880,309,210$ & $58,646,329,121$ \\
2013 & $313,664,019,262$ & $51,810,424,520$ \\
2014 & $376,694,285,634$ & $104,267,201,912$ \\
& & $102,898,339,772$ \\
2015 & $380,988,168,593$ & $93,871,952,310$ \\
2016 & $372,731,501,477$ & MKB-R (Rp) \\
RASIO & \multicolumn{2}{c}{$72,711,000$} \\
2010 & \multicolumn{2}{c}{$(140,970,000)$} \\
2011 & $294,233,980,089$ \\
2012 & $261,853,594,742$ \\
2013 & $272,427,083,722$ \\
2014 & $278,089,828,821$ \\
2015 & $278,859,549,167$ \\
2016 &
\end{tabular}

Berdasarkan perhitungan diatas, maka dapat diketahui bahwa rasio modal kerja PT. Mustika Ratu, Tbk. Dari tahun 2010 sampai tahun 2011 turun sangat signifikan dari Rp. 72,711,000 Ke Rp. $(140,970,000)$ karna naiknya utang lancar. sedangkan dari tahun 2012 ke tahun 2016 cendering naik meskipun tahun 2013 turun dikarenakan turunnya asset lancar.

${ }^{21}$ Data diolah dari laporan keuangan. Sumber : www.idx.co.id 
e. Rasio Persediaan terhadap Modal Kerja Bersih

Tabel 5 : Perhitungan Rasio Persediaan terhadap Modal Kerja Bersih PT. Mustika Ratu, Tbk. Tahun 2010-2016 ${ }^{22}$

\begin{tabular}{|c|c|c|c|}
\hline TAHUN & $\begin{array}{l}\text { PERSEDIAAN } \\
(\mathrm{Rp})\end{array}$ & $\begin{array}{c}\text { ASET LANCAR } \\
(\mathrm{Rp})\end{array}$ & $\begin{array}{c}\text { UTANG } \\
\text { LANCAR } \\
(\mathrm{Rp})\end{array}$ \\
\hline 2010 & $400,784,000$ & $1,524,322,000$ & $1,451,611,000$ \\
\hline 2011 & $462,013,000$ & $1,567,335,000$ & $1,708,305,000$ \\
\hline 2012 & $63,429,469,813$ & $352,880,309,210$ & $58,646,329,121$ \\
\hline 2013 & $68,057,379,761$ & $313,664,019,262$ & $51,810,424,520$ \\
\hline 2014 & $86,415,542,961$ & $376,694,285,634$ & $104,267,201,912$ \\
\hline 2015 & $78,917,127,036$ & $380,988,168,593$ & $102,898,339,772$ \\
\hline 2016 & $90,719,293,111$ & $372,731,501,477$ & $93,871,952,310$ \\
\hline RASIO & & PtMKB-R & \\
\hline 2010 & & $556.944 \%$ & \\
\hline 2011 & & $-328 \% x$ & \\
\hline 2012 & & $21,4 \%$ & \\
\hline 2013 & & $26 \%$ & \\
\hline 2014 & & $32 \%$ & \\
\hline 2015 & & $28 \%$ & \\
\hline 2016 & & $33 \%$ & \\
\hline RI & & $12 \%$ & \\
\hline
\end{tabular}

Tabel 6 : Perhitungan Rasio Likuiditas terhadap Modal Kerja Bersih PT. Mustika Ratu, Tbk. Tahun 2010-2016 ${ }^{23}$

\begin{tabular}{|ccccc|}
\hline TAH & \multirow{2}{*}{ KAS } & PERSE & ASET & UTANG \\
UN & & DIAAN & LANCAR & LANCAR \\
\hline \multirow{2}{*}{2010} & 999,240 & 400,784 & $1,524,32$ & $1,451,611$ \\
&, 000 &, 000 & 2,000 &, 000 \\
2011 & 918,974 & 462,013 & $1,567,33$ & $1,708,305$ \\
&, 000 &, 000 & 5,000 &, 000 \\
2012 & 59,560, & 63,429, & 352,880, & $58,646,32$ \\
& 929,387 & 469,813 & 309,210 & 9,121 \\
2013 & 55,331, & 68,057, & 313,664, & $51,810,42$ \\
& 076,348 & 379,761 & 019,262 & 4,520 \\
2014 & 36,038, & 86,415, & 376,694, & $104,267,2$ \\
& 513,893 & 542,961 & 285,634 & 01,912 \\
2015 & 36,273, & 78,917, & 380,988, & $102,898,3$ \\
& 186,840 & 127,036 & 168,593 & 39,772 \\
2016 & 24,376, & 90,719, & 372,731, & $93,871,95$ \\
& 706,961 & 293,111 & 501,477 & 2,310 \\
\hline
\end{tabular}

Berdasarkan tabel diatas, maka dapat disimpulkan bahwa rasio persediaan terhadap modal kerja cenderung naik dan likuid

${ }^{22}$ Data diolah dari laporan keuangan. Sumber : www.idx.co.id kecuali tahun 2011 yang turun sebesar $(327,74 \%)$ dan tahun 2010 yang cenderung mengalami kelebihan.

\section{KESIMPULAN DAN SARAN}

Berdasarkan perhitungan diatas, maka dapat disimpulkan bahwa rasio likuiditas PT. Mustika Ratu, Tbk. Tahun 2010-2016 yaitu sebagai berikut :

\begin{tabular}{|c|c|c|c|c|c|}
\hline RASIO & $\mathrm{CR}$ & QT & CAR & $\begin{array}{c}\text { MKB-R } \\
\text { (Rp) }\end{array}$ & $\begin{array}{l}\text { PtMKB- } \\
\mathrm{R}\end{array}$ \\
\hline 2010 & 1.05 & 0.77 & $68.84 \%$ & $72,711,000$ & $551.20 \%$ \\
\hline 2011 & 0.92 & 0.65 & $53.79 \%$ & $\begin{array}{c}(140,970,00 \\
0)\end{array}$ & $\begin{array}{c}- \\
327.74 \%\end{array}$ \\
\hline 2012 & 6.02 & 4.94 & $101.56 \%$ & $\begin{array}{c}294,233,98 \\
0,089\end{array}$ & $21.56 \%$ \\
\hline 2013 & 6.05 & 4.74 & $106.80 \%$ & $\begin{array}{c}261,853,59 \\
4,742\end{array}$ & $25.99 \%$ \\
\hline 2014 & 3.61 & 2.78 & $34.56 \%$ & $\begin{array}{c}272,427,08 \\
3,722\end{array}$ & $31.72 \%$ \\
\hline 2015 & 3.70 & 2.94 & $35.25 \%$ & $\begin{array}{c}278,089,82 \\
8,821\end{array}$ & $28.38 \%$ \\
\hline 2016 & 3.97 & 3.00 & $25.97 \%$ & $\begin{array}{c}278,859,54 \\
9,167\end{array}$ & $32.53 \%$ \\
\hline RI & $2 X$ & $1,5 \mathrm{X}$ & $50 \%$ & & $12 \%$ \\
\hline
\end{tabular}

Bahwa rasio lancar dan rasio cepat PT. Mustika Ratu, Tbk. Tahun 2010-2016 mengalami likuid-menurun meskipun tahun 2010 ke 2011 ill-likuid dikarenakan naiknya utang lancar dan turunnya asset lancar. Kemudian cash asset dari tahun 2010 ke 2013 dalam kondisi baik atau likuid tetapi tahun 2014 sampai 2016 ill-likuid menurun diakibatkan kas mengalami penurunan. Maka dapat disimpulkan bahwa CR dan QT PT. Mustika ratu, Tbk tahun 2010 - 2016 likuid artinya mampu membayar kewajiban lancarnya secara keseluruhan dan setekah dikurangi persediaan karena merupakan asset lancar yang kurang likuid. Sedangkan CARnya ill-likuid menurun artinya ketersediaan kas yang semakin menurun mengakibatkan kemampuan perusahaan membayar kewajiban lancarnya semakin menurun dan ill-likuid. Sedangkan rasio modal kerja bersih dan rasio persediaan terhadap modal kerja cenderung naik dan likuid.

${ }^{23}$ Data diolah dari laporan keuangan. Sumber : www.idx.co.id 
DAFTAR PUSTAKA

BRI. (2012). Sejarah dan Profil Singkat. Website BRITAMA. Diakses dari http://britama.com/index.php/2012/1 2/sejarah-dan-profil-singkat-mrat/

IDX. (2018). Profil Perusahaan Tercatat. Website IDX. Diakses dari http://www.idx.co.id/id$\mathrm{id} /$ beranda/perusahaantercatat/profilp erusahaantercatat.aspx

Fahmi, I. (2014). Analisis Laporan Keuangan. Bandung : Alfabeta.

Fraser, L. M. \& Ormiston, A. (2008). Memahami Laporan Keuangan Edisi Ke Tujuh. Jakarta : Indeks.

Kasmir. (2008). Analisa Laporan Keuangan. Jakarta : PT. Raja Grafindo Persada.
Munawir, S. (2008). Analisis Informasi Keuangan. Yogyakarta : Liberty.

Riyanto, B. (2001). Dasar - dasar Pembelanjaan Perusahaan. Yogyakarta: BPFE.

Weaver, S. C. \& Weston, J. F. Finance and Accounting for nonfinancial Managers. Memahami Laporan keuangan dan Akuntansi Sekelas MBA. (2001). Jakarta : PT. Buana Ilmu Populer.

Tempo. (2014). Penjualan Mustika Ratu Terkendala Distribusi. Tempo.co. Diakses dari https://bisnis.tempo.co/read/584236/ penjualan-mustika-ratu-terkendaladistribusi 